\title{
O futebol na proposta autoritária e corporativista da Era Vargas (1930-1945)
}

Luiz Carlos Ribeiro ${ }^{1^{*}}$

${ }^{1}$ Universidade Federal do Paraná, Curitiba/PR - Brasil

Jhonatan Uewerton Souza ${ }^{2 * *}$

${ }^{2}$ Instituto Federal de Educação, Ciência e Tecnologia do Paraná, Goioerê/PR - Brasil

\section{RESUMO}

Inserida no debate teórico e historiográfico do período varguista, a proposta do presente artigo é analisar a reestruturação do sistema organizativo do futebol brasileiro ocorrida no período. De forma mais específica, pretendemos investigar o papel que agentes internos e externos ao campo esportivo tiveram nesse processo.

Palavras-chave: Brasil; Era Vargas; corporativismo; futebol; CBD.

\section{Football in the authoritarian and corporatist proposal of the Vargas Era (1930-1945)}

\section{ABSTRACT}

This article intervenes in the theoretical and historiographic debate of the Vargas period. It analyzes the restructuring of Brazilian football's organizational system, which occurred during the period. More specifically, the article investigates the role of internal and external sports field agents in this process.

Keywords: Brazil; Vargas period; corporatism; football; CBD.

DOI: http://dx.doi.org/10.1590/2237-101X02204608

Artigo recebido em 22 de fevereiro de 2019 e aceito para publicação em 4 de abril de 2020 .

* Professor da Universidade Federal do Paraná / Setor de Ciências Humanas, Letras e Artes, Curitiba/PR Brasil. E-mail: ribeiro4650@gmail.com. ORCID: https://orcid.org/0000-0002-0889-4163.

** Professor do Instituto Federal de Educação, Ciência e Tecnologia do Paraná / Campus Goioerê, Goioerêl PR - Brasil. E-mail: jhonatanusouza@gmail.com. ORCID: https://orcid.org/0000-0002-4080-4973. 


\section{El fútbol en la propuesta autoritaria y corporativista de la Era Vargas (1930-1945)}

\section{RESUMEN}

Inserida en el debate teórico e historiográfico del periodo Vargas, la propuesta del presente artículo es analizar la reestructuración del sistema organizativo del fútbol brasileño ocurrida en este periodo. De forma más específica, pretendemos investigar el papel que los agentes internos y externos del campo deportivo tuvieron en este proceso.

Palabras clave: Brasil; Era Vargas; corporativismo; fútbol; CBD.

\section{Introdução}

O estudo sobre o desenvolvimento do futebol nas décadas de 1930 e 1940 encontra-se bastante difundido na pesquisa acadêmica (NEGREIROS, 1998; DRUMOND, 2014; GOMES-PINHEIRO, 2015). A relevância deve-se ao fato de ter sido nesse período que o futebol brasileiro adquiriu uma estrutura institucional e esportiva sólida, fenômeno que compreendeu o reconhecimento da Confederação Brasileira de Desportos (CBD) como entidade principal do desporto nacional, a legalização da profissão de jogador de futebol e a instituição de uma política de Estado para os esportes, com a criação, em 1941, do Conselho Nacional de Desporto (CND).

Por conta dessa reestruturação do campo esportivo, predomina na literatura a concepção de que a prática e a gestão esportiva desse período sofreram um processo de enquadramento arbitrário do poder estatal. Essa leitura não deve ser desconsiderada, embora necessitemos tomá-la com ressalvas. Seu maior equívoco consiste em desistoricizar os sujeitos do campo esportivo, na medida em que os toma como agentes passivos. Trata-se de uma análise que apresenta as estruturas do Estado e da gestão esportiva como instâncias isoladas e estanques. Em síntese, uma interpretação que aborda a reestruturação do campo esportivo como manifestaçáo externa ao meio, feita à revelia dos indivíduos nele envolvidos. Os agentes sociais do esporte são vistos como aliciados e esvaziados de vontades, vítimas passivas do Estado autoritário. Uma visão que dissimula a ação dos sujeitos nas mudanças implementadas pelo regime.

Um exemplo, nesse sentido, é a leitura de Tubino a respeito do estabelecimento do Decreto-Lei no 3.199, que criou em 1941 o CND:

Com este decreto, estava instalada no Brasil a burocratização e a cartorialização no esporte brasileiro, o que viria obstaculizar os fatos esportivos brasileiros por muito tempo. O próprio 
CND viria a consolidar a tutela estatal sobre o Esporte com as seguidas deliberaçóes que cada vez mais tiravam a autonomia das entidades esportivas (BRASIL, 2001, p. 4).

A compreensão que o autor estabelece é de que o enquadramento institucional que ocorreu sobre o esporte brasileiro, nesse período, se deu de forma unilateral, impedindo aos agentes do campo esportivo manifestar de forma autônoma seus interesses.

Manhães, referindo-se ao mesmo processo, afirma ter sido "desprezível" o "espaço de intervenção dos segmentos sociais [...] pela via das entidades civis". Conforme o autor, a sociedade civil estava "em conformidade com a proposta de ordem oficial, corporativa" vigente no Estado Novo (MANHÃES, 2002, p. 25). Apesar de reconhecer a possibilidade de terem existido tensóes e colaborações entre governo e entidades esportivas, o autor afirma que essas açôes foram irrelevantes e não se constituíram em foco de interesse do seu estudo: "O que nos interessa é o projeto hegemônico e não a dialética hegemonia-resistência", afirma (MANHÃES, 2002, p. 26).

João Saldanha, no prefácio do mesmo livro, classifica as medidas governistas como "autoritarismo totalitário e absoluto":

Se por um lado o governo, principalmente depois do início da década de 1940, tomou a si, decretou para si e se intrometeu em todos os segmentos da vida esportiva nacional, por outro, eivado de um profundo sentimento elitista e de autoritarismo, atrofiou todos os esportes, inclusive o futebol campeão do mundo (SALDANHA, 2002, p. 10).

Em pesquisa recente, Soares opõe de forma mecânica Estado e organizaçóes esportivas, definindo a reestruturação dos esportes como mera intervenção do poder público. É uma perspectiva que reproduz a visão romântica do futebol como expressão espontânea, pura e despolitizada da cultura nacional, em oposição às articulaçôes dos poderes estatais, estas sim políticas: "Os esportes, organizados de forma independente e liberal, não se harmonizavam com o processo de intervenção, centralização e controle da sociedade pelo Estado" (SOARES, 2015, p. 89).

A proposta do presente artigo é problematizar essa leitura, entendendo que a reestruturação da prática corporativa e autoritária gestada no período varguista compreende uma dialogia marcada por tensóes e convergências entre os diversos atores envolvidos nesse processo. Tomando como referência a atuaçáo de agentes estatais e do meio esportivo, pretendemos tensionar a tese, predominante na literatura, do caminho de mão única da intervenção do Estado na esfera privada do futebol ou mesmo na configuraçấo do campo esportivo como um todo. Desse modo, o estudo inscreve-se no debate teórico e historiográfico que averigua a relação entre as políticas jurídico-institucionais do Estado e a sociedade civil na Era Vargas. Entendemos "sociedade civil" aqui no sentido de uma contraposição ao Estado. A sociedade civil 
como a "esfera das relaçóes entre indivíduos, entre grupos, entre classes sócias, que se desenvolvem à margem das relaçóes de poder”, que caracterizam o Estado (BOBBIO, 1998, p. 1.210). Obviamente não pretendemos abordar a totalidade dessa sociedade, mas a indicação de alguns agentes diretamente envolvidos com a problemática da regularização do futebol no Brasil.

Interessa, nesse sentido, a descrição e análise da atuação de determinados "agentes de interesse”, presentes tanto na instância governamental quanto na esportiva. E de pensá-los atuando de forma dialógica na construção do projeto de disciplinarização e reorganizaçáo do campo esportivo brasileiro. Afinal, a compreensão da eficácia da ideologia estadonovista só é possível se pressupormos a existência de uma teia complexa de agentes que a legitime (OLIVEIRA-VELLOSO-GOMES, 1982).

É preciso ressaltar, de início, que a maioria dos dirigentes dos grandes clubes e entidades esportivas desse período pertenciam às elites dirigentes. Eram, na sua maioria, empresários dos mais variados ramos ou políticos ocupando funçôes diversas, tanto no poder legislativo quanto no executivo. Por vezes, esses indivíduos ocupavam cargos tanto no campo privado das instituiçôes esportivas quanto na esfera dos poderes públicos. De tal modo que devemos tratar as esferas esportiva e político-institucional como distintas e autônomas, mas não antinômicas. Ao inverso, elas se apresentam profundamente imbricadas e a circularidade de agentes entre elas é considerável.

Isso exige o esforço em compreender que a construção do autoritarismo corporativo do governo Vargas só foi possível com a participação ativa de diversos segmentos da sociedade, incluindo os agentes esportivos. O próprio campo esportivo é plural e atravessado por tensôes. Nele, estão dirigentes de grandes clubes, de agremiaçôes pequenas, de entidades governamentais responsáveis pela fiscalização dos esportes, jornalistas esportivos, atletas, árbitros, enfim, uma multiplicidade de indivíduos com interesses nem sempre convergentes.

Para compreendermos a complexidade desse processo, analisaremos a participaçáo de alguns agentes em momentos importantes da formação da estrutura corporativa varguista para a gestáo do esporte. É o caso da conjuntura da profissionalização do jogador de futebol, no início dos anos 1930, e do processo de "oficialização e pacificação dos esportes", que culminou no fortalecimento da CBD, sobretudo depois de 1936. Por uma questấo de espaço e pela sua complexidade, a criação e instalação, em 1941, do CND e dos respectivos Conselhos Regionais de Desportos (CRDs) será apenas mencionada.

Em síntese, o objetivo é demonstrar que as medidas de "hierarquização" e "ordem" que caracterizaram a reestruturação do campo esportivo no período não se constituíram apenas através da intervenção do poder público federal, mas também por meio da "participação negociada" de diversos agentes da sociedade civil. Correspondendo à ideologia disciplinadora do Estado Novo, muitas dessas açôes foram produzidas pela expertise dos agentes do próprio campo esportivo. Cabe, de início, problematizar como a ideologia corporativa e autoritária do regime de Vargas se insere e reconfigura a esfera pública. 


\section{Ordem e disciplina corporativa}

A proposta do corporativismo teria se originado como "uma tentativa de justificaçáo de uma relação particular entre o Estado e as organizaçóes econômicas". Uma estratégia de reduzir ou mesmo eliminar as "instituições políticas clássicas de representação dos interesses difusos da sociedade" (DOMINGOS FILHO, 2003, p. 68). O argumento é que a crise do Estado liberal exigia um rearranjo institucional que deveria perpassar a sociedade como um todo.

O corporativismo, assim, apresenta-se como um mecanismo de controle do Estado sobre a sociedade. Uma forma de aumentar a capacidade de gestáo do Estado sobre o capital e o trabalho. Uma doutrina que se propóe como soluçáo política aos embates como a luta de classes, a competição econômica e a diversidade ideológica, de modo a tornar possível a "solidariedade orgânica dos interesses concretos", procurando dissolver o conflito político entre esses mesmos interesses (BOBBIO apud DOMINGOS FILHO, 2003, p. 68). O que se desejava era dissipar as tensôes herdadas da tradição liberal, apresentando o Estado como a síntese harmonizada das vontades individuais ou de grupos.

$\mathrm{Na}$ experiência brasileira é preciso inquirir como essa "síntese harmonizada" das vontades, na perspectiva de diluir as tensôes, foi social e politicamente exercitada. Para além do conceitual acima descrito, é preciso considerar que a proposta de reorganização do Estado e da sociedade correspondeu ao anseio de diversos segmentos. Apenas como exemplos, podemos nos referir, no Brasil dos anos 1920/1940, às palavras de ordem do "movimento tenentista", ao reformismo autoritário da Ação Integralista Brasileira, às propostas centralizadoras do Partido Comunista Brasileiro, às manifestaçôes corporativas das federaçóes e sindicatos patronais e de trabalhadores além, evidentemente, do próprio staff varguista.

Afinal, como afirma José Murilo de Carvalho: "todo sistema de dominação, para sobreviver, terá de desenvolver uma base qualquer de legitimidade". Fora dessa possibilidade, só resta tomar os indivíduos como "vítimas impotentes das maquinaçôes do Estado ou de grupos dominantes" (CARVALHO, 1987, p. 11).

Se nesses anos 1930/1940 havia entre os grupos políticos mais atuantes algum consenso de que o regime liberal se encontrava falido, eles não eram unânimes sobre a forma como deveria ser reordenado o Estado e a sociedade. O projeto de corporativização da sociedade brasileira passou por um intenso debate, em que muitos discursos atuaram no sentido de construir e disseminar uma proposta minimamente coesa e eficaz.

Um dos elaboradores dessa proposta foi Azevedo Amaral (1881-1942), quando define a forma de participação da sociedade civil nessa construção:

É dos sindicatos que devem partir, para convergirem no Estado, as expressōes múltiplas das correntes que formam, no seu conjunto, a vontade nacional e podem ser consideradas como autênticas forças representativas de nação (AMARAL, 1938, p. 183). 
É das organizaçôes da sociedade civil que, de forma hierárquica e disciplinada, deve emanar a vontade nacional, configurando-se desse modo o Estado autoritário como uma "democracia autêntica" (AMARAL, 1938, p. 185). Fica clara a intenção de eliminar as pressóes oligárquicas e patriarcais tradicionais, a favor de modernas estruturas corporativas, tais como sindicatos ou instituiçóes sociais de controle civil (VIANNA, 1987, p. 126).

A proposta era garantir o direito à representaçáo, desde que esta se fizesse dentro da ordem e da disciplina propostas pelo Estado. A questão é que a elaboração desse programa teve de passar necessariamente por diversas instâncias sociais. Apesar da proposta corporativa do Estado Novo ser uma inclusão vigiada do cidadão na política, dada a multiplicidade de atores em jogo, a negociação, as alianças e disputas fizeram parte da sua construção. Afinal, o próprio controle autoritário e populista necessitava de "um espaço de livre expressão das massas, para então transformar em doaçóes, apropriando-se, com antecedência, de qualquer projeto autônomo alternativo" (GOMES, 1996, p. 12).

Em artigos recentes, Adriano Codato discute a implantação do regime autoritário no Estado Novo, sob a perspectiva da relaçáo entre o Estado central e as elites regionais. Interessa-lhe analisar "a aparelhagem política que permitiu que o governo federal regulasse as relaçóes de poder com as classes dirigentes estaduais" (CODATO, 2011, p. 321). O autor busca compreender "como foi possível desmontar não só os esquemas oligárquicos tradicionais de negociação e solução de conflito intra-elites, mas aniquilar seus recursos institucionais - em especial, partidos e parlamentos" (CODATO, 2011, p. 323).

Codato argumenta na perspectiva de superar o lugar comum do processo de centralização do poder no Estado Novo, ao procurar saber "como se efetivou concretamente esta dominância" (CODATO, 2011, p. 322). A conclusão que extrai é que foi através de arranjos políticos e institucionais, como a interventoria e os Departamentos Administrativos estaduais, que o governo federal pôde executar seu controle. Ao se negar a aceitar esse processo como mera cooptação - que supóe um processo intencional de aliciamento, a fim de esvaziar grupos ou lideranças -, Codato propóe a categoria gramsciana de "transformismo da elite política" para explicar esse processo de alargamento do Estado. Conceito que reproduz do próprio pensador italiano:

Transformismo, por sua vez, implica a fabricação "de uma classe dirigente cada vez mais ampla, [...] com a absorção gradual, mas contínua, e obtida com métodos de variada eficácia, dos elementos ativos surgidos dos grupos aliados e mesmo dos adversários e que pareciam irreconciliavelmente inimigos" (GRAMSCI apud CODATO, 2015, p. 322).

É um conceito que tensiona o binarismo Estado-sociedade civil, no qual o "vazio de classes" serve apenas para autenticar um Estado todo poderoso, obscurecendo a sua constituição. Afinal, para compreendermos o Estado autoritário precisamos olhar tanto para o 
Estado quanto para a sociedade civil, pois é no interior desta que ele se gesta. Resta, agora, analisarmos como esse processo se deu em relação aos agentes do campo esportivo.

\section{A reestruturação do campo esportivo e a questáo do profissionalismo}

A década de 1930 marca, no campo esportivo, a consolidação do futebol como um esporte de massas. O processo de popularizaçáo do futebol, a transiçáo do amadorismo para o profissionalismo e a massificação desse fenômeno esportivo, com o surgimento de clubes e atletas com grande apelo popular foram fenômenos estudados por diversos autores, com destaque para Pereira (2000), Franzini (2003) e Coutinho (2014). Na esteira da grande visibilidade alcançada pelo futebol nas décadas de 1930 e 1940, diversos literatos passaram a mobilizar o esporte bretão para fins de edificação de uma identidade nacional com apelo no imaginário popular, como indicam as investigaçôes de Antunes (2004), Hollanda (2004) e Capraro (2013). Na impossibilidade de tomarmos essa abrangência, nosso estudo ficará restrito à análise de alguns dirigentes e cronistas esportivos.

Nesse sentido, duas questôes centrais ocupavam a agenda dos dirigentes esportivos: a da profissionalização dos futebolistas e as pretensôes de intervenção estatal na organização e gestáo do campo esportivo.

A respeito do processo de adoção do profissionalismo no futebol brasileiro, estudiosos relacionam diretamente a profissionalização do atleta de futebol à ascensão de Getúlio Vargas ao poder, em 1930. Caldas, por exemplo, não apenas afirma que o Estado pressionou os "cartolas conservadores" para a adoção do profissionalismo, como insinua que o projeto de profissionalização do futebol seria uma agenda da gestão Vargas, desde sua ascensão ao poder (CALDAS, 1994, p. 45). Entretanto, quando analisamos o processo de profissionalização do futebol brasileiro percebemos que os debates sobre o tema antecedem, em muito, o governo Vargas. Além disso, as açóes dos agentes ligados a Vargas foram mais contraditórias e vacilantes do que pode sugerir uma leitura apressada e intuitiva desse processo.

Pesquisas recentes indicam que, ainda na década de 1910, o semiprofissionalismo era relativamente comum nas principais ligas futebolísticas de diversas cidades brasileiras. Havia, inclusive, um mercado incipiente que chegou a movimentar migraçóes intermunicipais, interestaduais e, por vezes, até mesmo internacionais de atletas (GOMES-PINHEIRO, 2015).

As transferências de jogadores em troca de prêmios, empregos e remuneraçóes eram táo constantes que a imprensa esportiva e os clubes começaram a pressionar as ligas e federaçóes para que incluíssem em seus regimentos normas que regulamentassem e inibissem essas transferências. Foi desse modo que surgiu, no Rio de Janeiro, em 1917, a Lei do Estágio, aprovada pela Liga Metropolitana de Desportos Terrestres (LMDT). Em São Paulo, em 1919, a Associação Paulista de Sports Atléticos (APSA) proibiu as excursôes de equipes lo- 
cais a outros estados e negou os pedidos de transferência protocolados por atletas vinculados àquela entidade, até que "a Confederação Brasileira aprove uma lei estabelecendo o estágio, pelo menos de um ano, para a transferência de jogador de um para outro Estado".

No Brasil, como ocorria em todo o mundo futebolístico, enquanto alguns clubes e sportsmen relutavam em reconhecer e legalizar as práticas de remuneração de atletas, outros passaram a pressionar os dirigentes por melhores rendimentos esportivos. Os atletas reivindicavam assistência médica em caso de lesão ou transferiam-se para outra agremiação sempre que conseguiam negociar melhores condiçôes de trabalho (NEGREIROS, 1998; SANTOS, 2010, p. 280). Portanto, quando Vargas ascendeu à presidência da República, em 1930, o processo de profissionalização do futebol brasileiro já havia avançado de forma significativa.

Nessa conjuntura, em janeiro de 1933, no Rio de Janeiro, os dirigentes do Bangu, Fluminense, América e Vasco da Gama, todos defensores do profissionalismo, romperam com a Associação Metropolitana de Esportes Atléticos (AMEA) - entidade que, assim como a Confederação Brasileira de Desportos (CBD), se negava a aceitar o profissionalismo - e fundaram a primeira liga profissional do país, a Liga Carioca de Football (LCF). Seguindo o exemplo carioca, a Associação Paulista de Esportes Atléticos (APEA) também oficializou o regime profissional.

Desfalcados, pois seus jogadores mais habilidosos haviam migrado para outros países em busca de melhores condiçôes de trabalho, os principais clubes de São Paulo e Rio de Janeiro passaram a assediar atletas de cidades menores e de outros estados, oferecendo vantagens e remuneraçóes para que se transferissem para os dois grandes centros. Entre $1932 \mathrm{e}$ 1933, nada menos que quinze atletas saíram da capital paranaense com destino às equipes paulistas e cariocas (SOUZA, 2014, p. 235). Segundo Marcus Lage, movimento análogo ocorreu em Belo Horizonte, o que terminou por pressionar a adoçáa do profissionalismo naquela cidade (LAGE, 2015, p. 142).

Em resposta à relutância da $\mathrm{CBD}$ em reconhecer o profissionalismo do futebol em âmbito nacional, a LCF, a APEA, a Federação Fluminense de Futebol (FFF), a Associação Mineira de Esportes (AME) e a Federação Paranaense de Desportos (FPD) formaram, em 1933, a Federação Brasileira de Futebol (FBF), com o objetivo de representar o futebol profissional no país. No próprio campo esportivo, entretanto, existiam divergências quanto à conveniência da adoção do profissionalismo. Cidades com larga tradição no futebol, como Recife e Porto Alegre, mantiveram suas ligas amadoras e alguns clubes relevantes no cenário nacional, como o Botafogo, se negaram a aderir à profissionalização. Igualmente, no Flamengo o debate em torno da profissionalizaçáo era tenso, envolvendo membros da diretoria, sócios e mesmo atletas, como fica claro nesse pronunciamento no Jornal dos Sports do jogador Rubens, em 1933: "Se eu chegar ao profissionalismo, não me envergonharei. Minha

${ }^{1}$ SPORT. Commercio do Paraná, Curitiba, p. 2, 31 jul. 1919. 
opinião pessoal é favorável ao profissionalismo, pois julgo que esse é um meio de vida honesto como outro qualquer" (apud COUTINHO, 2013, p. 60).

O "dissídio esportivo", como ficou conhecido esse período de cisão entre as ligas amadoras, lideradas pela $\mathrm{CBD}$, e as profissionais, filiadas à $\mathrm{FBF}$, perdurou até 1937, quando o campo esportivo passou por novo processo de reunificação (DRUMOND, 2019).

Se por um lado a legislaçáo trabalhista emergente apontava no sentido da regulamentação de profissôes existentes, por outro, a ação no campo esportivo de alguns agentes ligados a Vargas indicava certa resistência à mercantilização da prática esportiva. Entendiam esses que o esporte deveria cumprir uma função eminentemente educativa, responsável pelo aprimoramento físico da nação e pela promoção do civismo (PARADA, 2006).

Assim como ocorreu no terreno político, a partir de 1930 o campo esportivo assistiu a um movimento de renovaçáo do quadro diretivo de diversas ligas e federaçôes do país. No Rio de Janeiro, por exemplo, nomes como Rivadávia Correa Meyer e Luiz Aranha, ambos ligados ao Botafogo, assumiram, respectivamente, a presidência da AMEA e a direção do Conselho Administrativo da CBD, substituindo o grupo político liderado por Arnaldo Guinle, do Fluminense, que controlou as entidades esportivas cariocas durante boa parte das décadas de 1910 e 1920 (SOUZA, 2008, p. 41-45; DRUMOND, 2015, p. 79). No Paraná, por sua vez, dois militares que participaram diretamente da Revolução de 1930, Francisco de Paula Soares Neto, do Britânia S. C., e Antônio Couto Pereira, do Coritiba F. C., assumiram o controle das entidades esportivas locais, alterando a correlaçáo de forças no interior do campo esportivo paranaense, que até então pendia para as famílias tradicionais da elite republicana de Curitiba, invariavelmente associadas ao Clube Athletico Paranaense (PEREIRA, 2014, p. 23-78).

Dentre os novos dirigentes que emergiam no campo esportivo, aquele que mais destaque obteve foi Luiz Aranha. Irmão de Oswaldo Aranha - ministro da Justiça, Fazenda e Relaçôes Exteriores de Vargas -, fundador do Clube 3 de Outubro e amigo pessoal de Getúlio, Luiz Aranha foi o principal articulador do novo governo no interior das instituiçóes diretivas do esporte nacional, assumindo os cargos de diretor do Conselho Administrativo da CBD, entre 1933 e 1936, e presidente da entidade, entre 1936 e 1943 (DRUMOND, 2015, p. 79). Sua atuação no contexto de adoção do profissionalismo no futebol brasileiro dá a medida das contradiçóes internas do governo Vargas em relação ao tema.

Ligado ao Botafogo, único grande clube carioca a se manter amador depois de 1932, Luiz Aranha permaneceu fiel à CBD no período de dissídio esportivo - opondo-se, portanto, aos defensores do profissionalismo reunidos na FBF. Mais que apoio, Aranha mobilizou aliados em diversos estados, com intuito de frear o processo de adesão à nova liga profissional. Foi esse, por exemplo, o caso do Paraná. Depois de um longo debate na imprensa local sobre as vantagens e desvantagens do regime profissional, em 14 de dezembro de 1933, o presidente da FPD, Francisco Paula Soares Neto, pressionado pelos clubes filiados à entidade, convocou 
uma assembleia geral para deliberar sobre os caminhos que a federação tomaria em relação ao dissídio - se permaneceria na amadora CBD ou se entraria na profissional FBF (SOUZA, 2014, p. 237-239).

Conforme noticiou o periódico $O$ Dia, ao tomar conhecimento da convocação da assembleia, Luiz Aranha enviou um telegrama a Paula Soares, de quem era próximo, solicitando esclarecimento sobre as notícias publicadas em "jornais profissionalistas" que "alardeavam haver a FPD solicitado inscrição na Federação Brasileira de Futebol”. ${ }^{2}$ Assim como Aranha, Paula Soares era "tenente revolucionário", tendo atuado na linha de frente das tropas insurgentes em Curitiba e São Paulo, em 1930. A atuação lhe rendeu a patente de capitão e criou as bases para sua posterior inserção no mundo político. Alinhado a Vargas, Paula Soares foi eleito deputado pelo PSD, em 1933, enquanto no campo esportivo ocupava a presidência da FPD.

Em resposta ao telegrama do aliado carioca, Soares informou que havia entre os clubes de Curitiba um "formidável descontentamento" com a desorganização da CBD, em função do atraso na realização do campeonato nacional. Mesmo assim, Soares afirmou que trabalharia pela não adesão da FPD à entidade profissional (PEREIRA, 2014, p. 53-56).

Essa não era a primeira vez que Luiz Aranha tentava intervir nas posiçóes das federaçóes regionais. Conforme O Dia, em junho de 1933, diante da neutralidade da FPD em relaçáo ao dissídio esportivo, Aranha tentou articular com Manoel Ribas, interventor do Paraná, o apoio da federação local à ala amadora da CBD. O mesmo ocorreu em relaçáo a outras federaçốes regionais, como Santa Catarina e Rio Grande do Norte. ${ }^{3}$

A negativa de Manoel Ribas ao pedido de Aranha indica, ainda, que dentro do próprio bloco de poder varguista não havia um consenso sobre a melhor forma de intervir no campo esportivo. Enquanto Aranha solicitava a intromissão do interventor paranaense nos assuntos da federação local, Ribas adotava uma posição de neutralidade, respeitando a autonomia das instituiçóes do campo esportivo. Outros interventores, como Aristiliano Ramos, de Santa Catarina, demonstravam menor pudor em interferir nos assuntos esportivos, como indica nota da imprensa:

Em ediçóes anteriores, esta folha publicou um despacho telegráfico do interventor de Santa Catarina ao seu colega do Paraná, no qual, aquele, em nome da Liga Náutica do seu Estado, apela para este, no sentido de conseguir dos dirigentes do esporte paranaense, as suas simpatias para o movimento liderado pela referida Liga, em prol da pacificaçấo do esporte nacional. ${ }^{4}$

O cotejo das açôes de dirigentes esportivos ligados em maior ou menor grau a Vargas inviabiliza qualquer leitura esquemática do processo de profissionalização do futebol brasileiro

${ }^{2}$ O DIA esportivo. O Dia, Curitiba, p. 6, 16 dez. 1933.

${ }^{3}$ O DIA esportivo. O Dia, Curitiba, p. 6, 14 jun. 1933.

${ }^{4}$ O DIA esportivo. O Dia, Curitiba, p. 6, 27 out. 1933. 
que venha a opor, de um lado, um Estado inclinado a reconhecer a profissão de jogador de futebol, e, do outro, dirigentes esportivos autônomos contrários à profissionalização. Tanto no interior do campo esportivo quanto no interior das estruturas estatais havia defensores do amadorismo e do profissionalismo.

É simplista, portanto, atribuir aos "dirigentes esportivos" - entendidos como um bloco coeso e unificado - uma resistência intransigente ao processo de profissionalizaçáo. De outro modo, as iniciativas pelo reconhecimento do regime profissional partiram do próprio campo esportivo, sendo defendidas, muitas vezes, por dirigentes que pretendiam frear o processo de exportação de futebolistas para ligas profissionais estrangeiras ou para as grandes cidades brasileiras. Igualmente reducionista é desprezar as contradiçôes internas do governo Vargas no tocante à profissionalização esportiva.

\section{Projetos de intervenção do Estado na organização esportiva}

Concomitantemente à questão do profissionalismo, outro tema que tensionava as relaçôes, tanto no bloco governista quanto no meio esportivo, era a conveniência ou não de uma intervenção direta do Estado na organização dos esportes nacionais. De início, cumpre alertar que o histórico de ingerências políticas no campo esportivo antecede a Era Vargas.

Como demonstram diversos estudos, à medida que as entidades esportivas cresceram em número de associados, elas se converteram em espaços privilegiados para a "caça de votos" (MELO, 2006; RODRIGUES, 2010). No Paraná, por exemplo, desde o início da década de 1920 facções distintas do Partido Republicano Paranaense disputavam entre si o controle da Associação Sportiva Paranaense (ASP), como denunciava a imprensa. ${ }^{5}$

Portanto, quando Vargas assumiu a presidência, já havia um histórico de entrelaçamento entre as instituiçóes políticas e o campo esportivo. Além disso, a crise geral do liberalismo tinha causado seus efeitos também no interior das entidades esportivas. Enfadados com os sucessivos conflitos, cisôes e reunificaçôes no interior das ligas e federaçôes do país, muitos cronistas, no início da década de 1930, passaram a desacreditar a capacidade de auto-organização dos esportistas e a eficácia do modelo liberal de organização institucional para a superação das divergências entre clubes, ligas e federaçôes.

Em 1931, por exemplo, o periódico O Dia, de Curitiba, abriu uma campanha pública contra a realização de Assembleias Gerais pela FPD. Conforme um cronista do periódico, os representantes dos clubes nas assembleias "nunca discutiram os fatos, não procuraram conhecer da sua legalidade ou ilegalidade, votando mediante 'cabala". E complementa: "A voz dos raros esportistas sensatos sempre foi abafada pela da maioria acarneirada". ${ }^{6}$ Em 1932, o

\footnotetext{
${ }^{5}$ DESPORTOS. Gazeta do Povo, Curitiba, p. 3, 7 fev. 1923.

${ }^{6}$ O DIA esportivo. O Dia, Curitiba, p. 7, 6 set. 1931.
} 
mesmo cronista foi além, conclamando a intervenção de um ditador para colocar ordem no esporte paranaense:

Um ditador, senhores! Um ditador... ou lá se vai tudo quanto Martha fiou! Mas um ditador com pulsos de aço para dar sinagoga dessa hidra maldita de cem cabeças e mil tentáculos, polvo sugador que ameaça envolver em tramas destruidoras o nosso já táo depauperado esporte. [...] Venha o homem: o Jesus do esporte paranaense! "Enforquem-se" - ainda que seja provisoriamente - os Iscariotes de todas as cores. [...] O momento é azado para uma desinfecçấo saneadora. [...] Nada de contemporizaçôes. Venha a nós o Getúlio Vargas do esporte! Estamos enfim livres das peias 'constitucionais'. Mãos à obra, senhores! Destrua-se e reedifique-se.'

Outro exemplo de afinidade com o intervencionismo era o do cronista esportivo Thomaz Mazzoni, de São Paulo, como verificamos nesse enfático comentário:

Facçóes, clubismo, pessoalismo, liberalismo, anarquias, tudo isso é lixo que a oficializaçáo deve queimar para o bem do esporte brasileiro. Necessitamos do império da obediência, da disciplina, e de um só comando, de um único objetivo para atingir e, portanto, todos devemos marchar por um único sentido, ouvindo e respeitando a voz do comando (apud NEGREIROS, 1998, p. 213).

Nem todos os agentes do campo esportivo, entretanto, apoiavam as saídas autoritárias para as sucessivas crises nas federaçóes. Era o caso do então presidente da FPD, Luiz Guimarães, que, em resposta à campanha de $O$ Dia contra a realização de assembleias gerais pela entidade, reafirmou a importância dos princípios liberais e democráticos na organizaçáo administrativa das instituiçóes esportivas:

Se se trata, porém, de um poder superior, cuja instituição suprima a Assembleia Geral, não sou ao mesmo favorável, por motivos diversos: primeiro, pela dificuldade com que lutaríamos para encontrar num ambiente apaixonado um "Messias" de que necessitamos; e depois, porque eu tenho para mim que as Assembleias, garantidoras da liberdade de pensamento e de ação de todos os filiados à Federação representam uma conquista democrática, que devemos, neste momento, mais do que nunca, amparar, ao invés de exterminar. ${ }^{8}$

No interior do bloco de poder varguista inexistia, igualmente, um consenso a respeito do que fazer em relação aos conflitos internos do campo esportivo. Em face à popularidade do futebol e à relevância cada vez maior das competiçôes internacionais no plano

${ }^{7}$ O DIA esportivo. O Dia, Curitiba, p. 6, 12 abr. 1932.

${ }^{8}$ O DIA esportivo. O Dia, Curitiba, p. 7, 14 jun. 1931. 
diplomático, o esporte não poderia ser negligenciado no interior do projeto de construção nacional capitaneado por Vargas. Nesse sentido, a experiência internacional, notadamente a italiana e alemã, informava a prática local. Na Itália, em 1930, o controle estatal sobre o esporte de competição se dava por meio do Comitê Olímpico Nacional Italiano (CONI) e, na Alemanha, em 1934, foi fundada a Liga do Reich Alemão para Exercícios Físicos, com o fim de supervisionar as federaçóes esportivas nacionais (DRUMOND, 2014, p. 147-148).

Enquanto isso, no Brasil, os conflitos entre dirigentes esportivos repercutiam negativamente na atuação das delegaçôes locais em competiçôes internacionais, reforçando a tese da intervenção. Por conta das disputas entre São Paulo e Rio de Janeiro pelo controle do futebol nacional e a disputa entre profissionais e amadores, a participação do Brasil na Copa de 1930, no Uruguai, foi um fracasso. Na Copa de 1934, na Itália, o selecionado nacional foi chefiado por Lourival Fontes, diretor do Departamento de Propaganda e Difusão Cultural e intelectual identificado com o fascismo. Mesmo com a interferência governamental, o resultado esportivo foi igualmente pífio.

No mesmo ano, o Decreto no 24.531, de 2 de julho de 1934, que regulamentava os serviços da Polícia Civil do Distrito Federal (BRASIL, 1934), estabeleceu que os eventos esportivos deveriam ter aprovação prévia do chefe da Censura Teatral e de Diversóes Públicas da Polícia Civil, tendo de informar todos os dados do evento, chegando mesmo a tentar controlar a conduta dos jogadores em campo, aplicando-lhes multa ou suspensóes quando estes não se portavam de maneira adequada durante a partida (DRUMOND, 2009, p. 225).

Em 1936, Luiz Aranha assumiu a presidência da CBD, cargo que ocupou até 1943, aproximando ainda mais a entidade do governo. Nesse ano, nos preparativos da delegação brasileira para as Olimpíadas de 1936, mais uma vez o conflito entre dirigentes esportivos ameaçava comprometer o desempenho nacional na competição. A disputa entre ligas de futebol amadoras e profissionais se converteu em contenda entre entidades "ecléticas" - que abrigavam mais que um esporte em seu interior, como a CBD - e "especializadas" - que cuidavam apenas de uma modalidade esportiva, como a FBF e a Federação Brasileira de Remo. O conflito chegou ao extremo do envio de duas delegaçóes para os Jogos Olímpicos daquele ano. $\mathrm{O}$ caso só foi resolvido às vésperas da cerimônia de abertura, por intervençấo direta de Getúlio Vargas em favor da união das delegaçôes (DRUMOND, 2009, p. 226-227).

A chamada "pacificação dos esportes", com a reunificação das entidades esportivas, viria no ano seguinte. Proposto pelos clubes da Vasco da Gama e América, do Rio de Janeiro, o acordo definia que os clubes deveriam se filiar a uma única entidade estadual, essa entidade se filiaria à federação "especializada" que representava sua modalidade esportiva em âmbito nacional (FBF, FBR etc.) e todas as federaçôes especializadas se filiariam à CBD. Assim, a organização dos esportes em âmbito nacional caberia às federaçôes especializadas e suas filiadas estaduais, enquanto a representação em competições internacionais ficaria a cargo da CBD (DRUMOND, 2009, p. 227-229) Ao mesmo tempo em que a "pacificação" dava a 
tônica no plano esportivo, o campo político era marcado pelo início do Estado Novo, com o endurecimento do projeto corporativista em relação à sociedade civil.

Com o fim do "dissídio esportivo", a CBD pôde se dedicar com antecedência à preparação da seleção brasileira que disputaria a Copa do Mundo de Futebol de 1938, tendo obtido um ótimo terceiro lugar. É possível que o sucesso na Copa do Mundo de 1938 tenha acelerado o processo de intervenção federal nas organizaçôes esportivas - que vinha se disseminando desde o início de 1930 -, mas não podemos ignorar as insinuaçôes de controle corporativo do Estado.

O primeiro projeto nesse sentido foi apresentado pela Liga de Sports da Marinha (LSM), em 1934, no contexto de cisão entre a CBD e a FBF, mas não logrou êxito. A ideia de repassar a gestáo dos esportes às forças armadas, entretanto, apareceria em outras ocasióes. Em 1935, um novo projeto de intervenção foi redigido por Hugo Gauthier, secretário do ministro da Justiça e diretor da seção de educação física do Departamento Nacional de Educação Physica. Em comparação à proposta da LSM, o modelo de oficialização idealizado por Gauthier preservava mais a autonomia das entidades esportivas: "a hipótese de uma imposição oficial às entidades, indicando-lhes diretrizes rígidas já não é cogitada, embora em torno da finalidade da oficialização tenham surgido discussōes".

Assim como a primeira proposta, o projeto de Gauthier náo chegou a ser encaminhado ao parlamento. O tema da oficialização voltaria em meados de 1936, quando os periódicos noticiaram que Pitta de Castro, diretor da Censura Teatral no Distrito Federal, embarcaria para a Alemanha nazista, junto com a delegação olímpica da CBD, com objetivo de estudar "a organização dos sports, sobretudo a sua direção, a fim de poder apresentar aqui um projeto bem fundamentado para regulamentar o movimento esportivo". ${ }^{10}$ As opiniōes continuavam divergentes:

Nos meios esportivos da cidade circula novamente com foros de verdade a notícia de que o governo pretende oficializar os sports. Há muitos meses esse assunto vem sendo discutido. Algumas figuras de relevo de departamentos oficiais, tais como os srs. Lourival Fontes e Israel Souto, têm animado tal ideia, repudiada por uns, mas apoiada calorosamente por outros. [...] Os primeiros alegam que o sport só progredirá com a iniciativa particular, pois a burocracia o asfixiará. Os segundos apoiam-na, certos de que o governo está na obrigação de controlar o aperfeiçoamento físico do povo. ${ }^{11}$

Apenas em outubro de 1936 um projeto de oficialização dos esportes foi efetivamente enviado ao Congresso. O autor do projeto foi o então deputado Café Filho, que defendia a

\footnotetext{
${ }^{9}$ VAI funcionar o D. N. de Educação Physica. Jornal dos Sports, Rio de Janeiro, p. 1-4, 12 jul. 1935.

${ }^{10}$ UMA DISTINÇÃO da CBD. Jornal dos Sports, Rio de Janeiro, p. 1, 28 jun. 1936.

${ }^{11}$ VOLTA-SE a falar insistentemente na oficialização dos sports! Jornal dos Sports, Rio de Janeiro, p. 1-4, 10 jul. 1936.
} 
criação de um Departamento Nacional de Desportos Terrestres e Marítimos "que superintenderá os desportos no território nacional, sendo nele inscritas as entidades desportivas existentes ou que vierem a existir no país". ${ }^{12}$ Resgatando alguns elementos da proposta elaborada pela LSM, o projeto de Café Filho previa que o Departamento Nacional de Desportos seria dirigido por dois oficiais do Exército, dois da Marinha e um civil, todos indicados pelo Presidente da República. Em cada estado haveria um Departamento Regional de Desportos, controlado por um Delegado Regional Civil.

Dois pontos do projeto de Café Filho foram duramente criticados. Um que afirmava que os clubes que não se filiassem ao Departamento seriam considerados entidades clandestinas, outro que definia que nenhum clube poderia disputar partidas com equipes ou selecionados estrangeiros sem obter prévia aprovação do Departamento. O critério para concessão da licença deixa clara a preocupação com a imagem externa do país, desgastada pelas experiências das Copas de 1930 e 1934, e pelo imbróglio diplomático na Olimpíada de 1936.

O projeto de Café Filho foi duramente criticado pelo Jornal dos Sports, principal periódico esportivo do Brasil à época: "O projeto apresentado pelo deputado Café Filho à Câmara sobre a oficialização dos sports não satisfaz a nenhuma das facçôes que contendem e dele discordam a unanimidade de nossos sportsmen". ${ }^{13}$

Outra voz que se levantou contra o projeto foi a de Arnaldo Guinle, presidente da FBF e um dos responsáveis pela reorganização do Comitê Olímpico Brasileiro (COB), em 1935. Em carta aberta publicada no mesmo periódico, o paredro carioca criticou o "caráter militar" da gestão esportiva e defendeu que a direção de entidades esportivas deveria ser "compartilhada indistintamente, como tem sucedido até hoje, entre militares e civis, na melhor das comunhôes". No tocante à questão internacional, Guinle subiu o tom da crítica:

O sport internacional é organizado por entidades fundadas por instituiçóes nacionais de dezenas de naçóes, só admitem filiadas que satisfaçam uns tantos requisitos os quais, de modo algum, poderiam ser preenchidos por um organismo ditatorial como o Departamento Nacional de que se trata. Além desse aspecto, há o olímpico, que é dirigido por um organismo internacional independente, que não permite a ingerência senão dos comitês nacionais por ele promovidos. A adoção do projeto em apreço significaria o afastamento do Brasil das Olimpíadas, que constituem a maior aspiração esportiva de todas as naçôes bem organizadas. ${ }^{14}$

Guinle concordava com a necessidade de regulamentação dos esportes em âmbito estatal, mas discordava do modelo de intervenção, de clara inspiração corporativista, proposto por Café Filho: "o dever e mesmo conveniência do governo seria o de fazê-la [a oficialização]

\footnotetext{
${ }^{12}$ UM PROJECTO pitoresco do sr. Café Filho. Jornal dos Sports, Rio de Janeiro, p. 1, 8 out. 1936.

${ }^{13}$ UMA LONGA carta do Sr. Arnaldo Guinle. Jornal dos Sports, Rio de Janeiro, p. 1, 10 out. 1936.

${ }^{14}$ UMA LONGA carta do Sr. Arnaldo Guinle. Jornal dos Sports, Rio de Janeiro, p. 4, 10 out. 1936.
} 
aproveitando o que já existe de feito e que representa um esforço colossal, quase todo de iniciativa privada, sem entrar na vida interna dessa organização". ${ }^{15}$

No mesmo ano, o deputado Francisco de Paula Soares Netto que, como vimos, presidiu a FPD no início da década de 1930 e era um importante aliado de Vargas no Paraná, apresentou uma emenda ao projeto de reforma do Ministério da Educação, propondo a criação do Departamento Nacional de Sports no interior daquele ministério. Pela sua fórmula, em vez de criar um novo órgão, como propunha Café Filho, a administração dos esportes passaria à alçada de um departamento submetido à autoridade do ministro da Educação. Tendo em vista o fracasso dos projetos anteriores, rejeitados por setores do campo esportivo e da imprensa especializada, o parlamentar demonstrou cautela na apresentação da emenda, afirmando que antes de redigi-la definitivamente iria consultar os dirigentes da CBD e a FBF. ${ }^{16}$

O projeto de Paula Soares contou com a aprovação do governo federal que, conforme o Jornal dos Sports, pretendia "apressar a oficialização" e, para tanto: "O sr. Getúlio Vargas pediu aos deputados da maioria que votassem a emenda Padua [sic] Soares". ${ }^{17} \mathrm{O}$ apadrinhamento do presidente da República não foi suficiente para proteger de críticas. Segundo o mesmo periódico, a emenda era "uma maneira violenta de obrigar os clubes a submeterem-se à oficialização" e, se aprovada, o governo teria "absolutismo de poderes" na gestáo esportiva. ${ }^{18}$ Nos debates sobre a emenda Paula Soares, os redatores do Jornal dos Sports expuseram o posicionamento editorial sobre o assunto, afirmando que o Estado deveria assumir apenas a gestão da educação física e da prática esportiva para fins educacionais, mantendo a organização do esporte competitivo no âmbito das entidades privadas.

Nunca é demais frisar que há uma enorme diferença entre esporte como competição e educação física. A competição não deve interessar ao governo e a educação deve merecer, sem dúvida, a elaboração de um plano eficiente. Só a execução desse plano complexo, vasto, absorveria, por completo, o trabalho de um Departamento. ${ }^{19}$

Em paralelo ao apoio à emenda Paula Soares, Getúlio Vargas nomeou um homem de sua confiança para elaborar um novo projeto de oficialização dos esportes. O escolhido para a tarefa foi o capitão João Alberto, que tinha servido como interventor em São Paulo, chefe de polícia do Distrito Federal e, desde 1935, trabalhava no corpo diplomático de Vargas (FGV/ CPDOC, 2016). Nos meses finais de 1936, João Alberto visitou diversas federaçóes, num

\footnotetext{
${ }^{15}$ Idem.

${ }^{16}$ UMA NOVA fórmula para a oficialização dos sports. Jornal dos Sports, Rio de Janeiro, p. 1, 17 out. 1936.

${ }^{17}$ O GOVERNO quer apressar a oficializaçáo. Jornal dos Sports, Rio de Janeiro, p. 1, 3 jan. 1936.

${ }^{18}$ Idem.

${ }^{19}$ NOVAMENTE a oficialização. Jornal dos Sports, Rio de Janeiro, p. 2, 20 dez. 1936.
} 
evidente esforço de aproximação com as entidades do meio esportivo. ${ }^{20}$ Seu plano de oficialização, explicado em diversas entrevistas ao Jornal dos Sports, não diferia substancialmente de outros projetos apresentados anteriormente. O capitão propunha a criação de Departamento de Sports e Educação Physica, que controlaria as federaçôes esportivas do país, e seria dirigido por um Conselho Superior com doze membros, dentre eles: "um delegado dos sports do Exército, um delegado dos sports da Marinha, um delegado da CBD e um delegado do Conselho Nacional de Sports". ${ }^{21}$

O que mudava era o tom da proposta. Ciente da necessidade de legitimação da oficializaçáo junto aos clubes e federaçóes, João Alberto se apressou em assegurar que o futebol profissional não seria o foco da intervenção estatal: "Em uma oficialização dos esportes, em um trabalho para a energia da raça, não interessa o futebol profissional, uma diversão que o público paga e escolhe como quem escolheria um filme". ${ }^{22}$

Desse modo, as críticas de Arnaldo Guinle e do próprio Jornal dos Sports às outras propostas de oficialização pareciam ter sido assimiladas pelo governo, que se comprometia a direcionar seus esforços na promoção da educaçáo física e no auxílio a modalidades esportivas ainda não consolidadas.

Além do mais, Joáo Alberto prometia pesados investimentos públicos nos esportes como contrapartida à oficialização. ${ }^{23} \mathrm{O}$ capitão chegou a prometer a construção de 11 praças esportivas pelo governo ainda em 1937: "poderiam fazer estádios no molde em que foi levantado o Fórum Mussolini, em Roma, o qual por ser abaixo do solo é muito menos dispendioso". ${ }^{24}$

O projeto de oficialização elaborado por Joáo Alberto chegou a ser encaminhado ao Congresso para aprovação em fevereiro de 1937, mas, por conta de sucessivos adiamentos na votação, a proposta percorreu o ano sem ser apreciada. Em setembro, o idealizador do projeto era pessimista quanto à efetivação da oficializaçáo: "o problema tornou-se demasiado complexo para ser tratado num fim de governo e por isso creio que somente no futuro período presidencial é que o assunto poderá voltar a ser debatido". ${ }^{25}$ Efetivamente, o tema só voltaria à baila no ano seguinte, depois do golpe do Estado Novo.

$\mathrm{O}$ assunto era táo controverso, que nem todos os agentes ligados ao bloco de poder varguista aprovavam a intervenção estatal no campo esportivo. Luiz Aranha, por exemplo, preferia um esporte "oficial e não oficializado":

\footnotetext{
${ }^{20}$ ACOMPANHANDO de visu. Jornal dos Sports, Rio de Janeiro, p. 4, 16 dez. 1936.

${ }^{21}$ NA OFICIALIZAÇÃO pouco interessa ao governo o footbal profissional. Jornal dos Sports, p. 4, Rio de Janeiro, 6 fev. 1936.

${ }^{22}$ Idem.

${ }^{23}$ Idem.

${ }^{24}$ ESTÁ POR poucos dias a intervenção do governo. Jornal dos Sports, Rio de Janeiro, p. 4, 18 mar. 1936.

${ }^{25}$ ASSUNTO complexo demais para um fim de governo. Jornal dos Sports, Rio de Janeiro, p. 1, 14 set. 1937.
} 
[...] isto é, o apoio do Governo aos esportes respeitando a organização atual, até mesmo modificando-a para melhor. Naturalmente os poderes públicos teriam um representante nomeado junto à Confederação, cuja missão seria fiscalizar a aplicação dos auxílios oficiais e opinar, com voto decisivo, nos casos de competições esportivas internacionais. ${ }^{26}$

A pluralidade de projetos de intervenção do Estado na organização esportiva apresentada por diferentes agentes e instituiçóes que compunham o bloco de poder varguista não deixa dúvidas a respeito das divergências e incertezas que o assunto da incorporação da gestão esportiva à estrutura do Estado causava entre os correligionários de Vargas.

Finalmente, em 1939, o Presidente da República instituiu a Comissão Nacional de Desportos, com o objetivo de "realizar um minucioso estudo do problema dos desportos no país, e apresentar ao Governo Federal, no prazo de sessenta dias, o plano geral de sua regulamentação" (BRASIL, 1939).

A comissão demorou dois anos para finalizar seu trabalho, que deu origem ao Decreto-Lei 3.199, de 14 de abril de 1941, que estabeleceu "as bases de organização dos desportos em todo o país" (BRASIL, 1941). Estava criado o Conselho Nacional de Desportos (CND) e, nas respectivas unidades federativas, os Conselhos Regionais de Desportos (CRD). Com a ediçấo do decreto, se consumava, do ponto de vista do Estado, a oficialização dos esportes no Brasil. Mas, a recepçáo e a eficácia do decreto presidencial junto ao campo esportivo são uma história a ser melhor pesquisada. O certo é que a promulgação do referido Decreto-Lei não foi suficiente para trazer o ordenamento desejado. A começar pela própria implantaçáo das unidades estaduais, os CRDs. Há pouca pesquisa empírica e predomina um desconhecimento sobre a experiência concreta do CND e de suas unidades federativas, mas o que se constata é que os problemas da organização do futebol persistiram.

\section{Considerações finais}

Ao cabo, se analisarmos a trajetória dos diversos projetos apresentados, perceberemos que o divisor de águas entre o sucesso e o insucesso da proposta estava na dificuldade de encontrar respaldo à iniciativa na sociedade civil, especialmente nos clubes, federaçôes, torcedores e na imprensa especializada, espécie de porta-voz autoproclamada do campo esportivo.

É preciso ressaltar, ainda, que as reaçôes de setores da sociedade civil em relação às intençôes de intervenção estatal na organização dos esportes nem sempre foram negativas. Diversos dirigentes esportivos apoiavam a iniciativa e viam nela um possível fator de desenvolvimento do esporte nacional.

\footnotetext{
${ }^{26}$ CAMINHA para a realidade a oficialização dos esportes. Jornal dos Sports, Rio de Janeiro, p. 4, 21 jul. 1938.
} 
Portanto, nos parece demasiado reducionista creditar o processo de expansão da estrutura de Estado corporativista em direção ao campo esportivo a um ato unilateral e intransigente de Vargas, como se suas açóes governamentais fossem alheias às pressóes da sociedade e às contradiçóes do seu próprio grupo político. De forma diversa, o que vimos foi uma convergência de diversos agentes em direção ao controle centralizado do campo esportivo. Com objetivos diversos, mas não necessariamente antagônicos. Da parte do discurso estatal, evidencia-se a perspectiva do enquadramento do meio esportivo, querendo exercer sobre ele todo o poder, mas consciente da sua força e autonomia. Da parte de alguns dos principais dirigentes do esporte, sobretudo do futebol, como vimos aqui, é visível tanto a convicção ideológica em favor da intervenção, quanto o pragmatismo pelo poder, seja por querer se beneficiar do patrocínio do Estado, seja pelas disputas entre os diversos sujeitos por controle e poder no interior do campo esportivo.

\section{Periódicos}

ACOMPANHANDO de visu. Jornal dos Sports, Rio de Janeiro, p. 4, 16 dez. 1936. ASSUNTO complexo demais para um fim de governo. Jornal dos Sports, Rio de Janeiro, p. 1, 14 set. 1937.

CAMINHA para a realidade a oficialização dos esportes. Jornal dos Sports, Rio de Janeiro, p. 4, 21 jul. 1938.

DESPORTOS. Gazeta do Povo, Curitiba, p. 3, 7 fev. 1923.

ESTÁ POR poucos dias a intervenção do governo. Jornal dos Sports, Rio de Janeiro, p. 4, 18 mar. 1936.

O DIA esportivo. O Dia, Curitiba, p. 7, 14 jun. 1931.

O DIA esportivo. O Dia, Curitiba, p. 7, 6 set. 1931.

O DIA esportivo. O Dia, Curitiba, p. 6, 12 abr. 1932.

O DIA esportivo. O Dia, Curitiba, p. 6, 14 jun. 1933.

O DIA esportivo. O Dia, Curitiba, p. 6, 27 out. 1933.

O DIA esportivo. O Dia, Curitiba, p. 6, 16 dez. 1933.

O GOVERNO quer apressar a oficialização. Jornal dos Sports, Rio de Janeiro, p. 1, 3 jan. 1936. NA OFICIALIZAÇÃO pouco interessa ao governo o footbal profissional. Jornal dos Sports, p. 4, Rio de Janeiro, 6 fev. 1936.

NOVAMENTE a oficialização. Jornal dos Sports, Rio de Janeiro, p. 2, 20 dez. 1936.

SPORT. Commercio do Paraná, Curitiba, p. 2, 31 jul. 1919.

UM PROJECTO pitoresco do sr. Café Filho. Jornal dos Sports, Rio de Janeiro, p. 1, 8 out. 1936. 
UMA DISTINÇĀO da CBD. Jornal dos Sports, Rio de Janeiro, p. 1, 28 jun. 1936.

UMA LONGA carta do Sr. Arnaldo Guinle. Jornal dos Sports, Rio de Janeiro, p. 1, 10 out. 1936. UMA NOVA fórmula para a oficialização dos sports. Jornal dos Sports, Rio de Janeiro, p. 1, 17 out. 1936.

VAI funcionar o D. N. de Educação Physica. Jornal dos Sports, Rio de Janeiro, p. 1-4, 12 jul. 1935.

VOLTA-SE a falar insistentemente na oficialização dos sports! Jornal dos Sports, Rio de Janeiro, p. 1-4, 10 jul. 1936.

\section{Referências}

AMARAL, Azevedo. O estado autoritário e a realidade nacional. Rio de Janeiro: Livraria José Olympio Editora, 1938.

ANTUNES, Fatima. "Com o brasileiro não há quem possa!": futebol e identidade nacional em José Lins do Rego, Mário Filho e Nelson Rodrigues. São Paulo: Editora Unesp, 2004.

BOBBIO, Norberto. Sociedade civil. In: BOBBIO, N., MATTEUCCI, N., PASQUINO, G. Dicionário de Política. 11. ed. V. 2. Brasília: Editora UNB, 1998.

BRASIL. Decreto n. 24.531, de 2 de julho de 1934. Casa Civil: Brasília/DF. Disponível em: http://www2.camara.leg.br/legin/fed/decret/1930-1939/decreto-24531-2-julho-1934498209-publicacaooriginal-1-pe.html. Acesso em: 6 dez. 2016.

BRASIL. Decreto Lei n. 1.056, de 19 de janeiro de 1939. Disponível em: http://www2. camara.leg.br/legin/fed/declei/1930-1939/decreto-lei-1056-19-janeiro-1939-349204publicacaooriginal-1-pe.html. Acesso em: 10 fev. 2017.

BRASIL. Decreto Lei n. 3.199, de 14 de abril de 1941. Disponível em: http://www2. camara.leg.br/legin/fed/declei/1940-1949/decreto-lei-3199-14-abril-1941-413238publicacaooriginal-1-pe.html. Acesso em: 11 fev. 2017.

BRASIL. Ministério do Esporte. Política Nacional de Esportes. Subsídios da Câmara Setorial de Esporte para a elaboraçáo da Política Nacional de Esporte. Manoel Tubino (Relator). Brasília/DF, 2001.

CALDAS, Waldenyr. Aspectos sociopolíticos do futebol brasileiro. Revista USP, São Paulo, n. 22, 1994.

CAPRARO, André. Histórias de matches e intrigas da sociedade: a crônica literária e o esporte futebol. São Paulo: Annablume, 2013.

CARVALHO, José Murilo de. Os bestializados. O Rio de Janeiro e a república que não foi. São Paulo: Companhia das Letras, 1987. 
CODATO, Adriano. Estado Novo no Brasil: um estudo da dinâmica das elites políticas regionais em contexto autoritário. Dados, v. 58, n. 2, 2015.

CODATO, Adriano. Intervenção estatal, centralização política e reforma burocrática: o significado dos departamentos administrativos no Estado Novo. Revista do Serviço Público, v. 62, n. 3, 2011.

COUTINHO, Renato Soares. Um Flamengo grande, um Brasil maior: O Clube de Regatas do Flamengo e o imaginário político nacionalista popular (1933-1955). Tese (Doutorado em História) - Universidade Federal Fluminense, Niterói, 2013.

COUTINHO, Renato. Um clube grande, um Brasil maior: o Clube de Regatas do Flamengo e a construção do imaginário político nacionalista popular (1933-1955). Rio de Janeiro: 7 Letras, 2014.

DOMINGUES FILHO, João Batista. O desenvolvimento do Estado democrático e o corporativismo Brasileiro. Economia-Ensaios, Uberlândia, v. 17, n. 2/v. 18, n. 1, jul. e dez., 2003.

DRUMOND, Maurício. Estado Novo e esporte: a política e o esporte em Getúlio Vargas e Oliveira Salazar (1930-1945). Rio de Janeiro: 7 Letras, 2014.

DRUMOND, Maurício. O "dissídio esportivo" e o processo de profissionalização do futebol no Rio de Janeiro. In: GOMES, Eduardo S.; PINHEIRO, Caio L. M. (orgs.). Olhares para a profissionalização do futebol: análises plurais. Rio de Janeiro: Luminária Academia, 2015.

DRUMOND, Maurício. O esporte como política de Estado: Vargas. In: PRIORE, Mary Del; MELO, Victor Andrade (orgs.). História do esporte no Brasil. São Paulo: Editora Unesp, 2009, p. 217-229.

FGV/CPDOC. Biografia de João Alberto. 2016. Disponível em: http://cpdoc.fgv.br/ producao/dossies/FatosImagens/biografias/joao_alberto. Acesso em: 31 dez. 2016.

FRANZINI, Fábio. Coraçóes na ponta da chuteira: capítulos iniciais da história do futebol brasileiro (1919-1938). Rio de Janeiro DP\&A, 2003.

GOMES, Ângela de Castro. O populismo e as ciências sociais no Brasil: notas sobre a trajetória de um conceito. Tempo, Rio de Janeiro, v. 1, n. 2, 1996.

GOMES, Eduardo S.; PINHEIRO, Caio L. M. (orgs.). Olhares para a profissionalização do futebol: análises plurais. Rio de Janeiro: Luminária Academia, 2015.

HOLLANDA, Bernardo. O descobrimento do futebol: modernismo, regionalismo e paixão esportiva em José Lins do Rego. Rio de Janeiro: Biblioteca Nacional, 2004.

LAGE, Marcus. A “sociogênese” da profissão de jogador de futebol em Belo Horizonte/MG: aspectos da consolidaçáo social e da espetacularização futebolística na capital mineira. In: GOMES, Eduardo S.; PINHEIRO, Caio L. M. (orgs.). Olhares para a profissionalização do futebol: análises plurais. Rio de Janeiro: Luminária Academia, 2015. 
MANHÁES, Eduardo Dias. Política de esportes no Brasil. 2. ed. Rio de Janeiro: Paz e Terra, 2002.

MELO, Victor A. Remo, modernidade e Pereira Passos: primórdios das políticas esportivas no Brasil. In: Revista Esporte e Sociedade, Rio de Janeiro, n. 3., 2006.

NEGREIROS, Plínio J. L. A nação entra em campo: futebol nos anos 30 e 40. Tese (Doutorado em História Social) - Programa de Pós-Graduação em História Social, Universidade de São Paulo, São Paulo, 1998.

OLIVEIRA, Lúcia Lippi; VELLOSO, Mônica Pimenta; GOMES, Ângela M. Castro. Estado Novo. Ideologia e poder. Rio de Janeiro: Zahar, 1982.

PARADA, Maurício. Corpos físicos como corpos cívicos: práticas desportivas e educação física no Brasil sob o Estado Novo. In: SILVA, Francisco C.; SANTOS, Ricardo P. (orgs.). Memória social dos esportes, v. II. Editora Mauad, 2006. p. 155-183.

PEREIRA, Eduardo. Entre amadores e profissionais: os agentes políticos da oficialização do futebol profissional paranaense. Dissertação (Mestrado em História) - Programa de PósGraduação em História, Universidade Federal do Paraná, Curitiba, 2014.

PEREIRA, Leonardo. Footballmania: uma história social do futebol no Rio de Janeiro, 1902-1938. Rio de Janeiro: Nova Fronteira, 2000.

RODRIGUES, Marilita A. R. Esporte, cidade e modernidade: Belo Horizonte. In: MELO, Victor A. (org.). Os sports e as cidades brasileiras: transição dos séculos XIX e XX. Rio de Janeiro: Apicuri, 2010.

SALDANHA, João. Prefácio. In: MANHÃES, Eduardo Dias. Politica de esportes no Brasil. 2. ed. Rio de Janeiro: Paz e Terra, 2002.

SANTOS, João M. C. M. Revolução vascaina: a profissionalização do futebol e a inserção socioeconômica de negros e portugueses na cidade do Rio de Janeiro (1915-1934). Tese (Doutorado em História Econômica) - Programa de Pós-Graduação em História Econômica, Universidade de São Paulo, São Paulo, 2010.

SOARES, Jorge Miguel Acosta. Justiça desportiva: O Estado Novo entra em campo (19411945). Tese (Doutorado em História Social) - Programa de Pós-Graduação em História, Pontifícia Universidade Católica de São Paulo, São Paulo, 2015.

SOUZA, Denaldo A. O Brasil entra em campo: construçóes da identidade nacional (19301947). São Paulo: Annablume, 2008.

SOUZA, Jhonatan U. O jogo das tensôes: clubes de imigrantes italianos no processo de popularização do futebol em Curitiba (1914-1933). Dissertação (Mestrado em História) Programa de Pós-Graduação em História, Universidade Federal do Paraná, Curitiba, 2014. VIANNA, Oliveira. Instituiçôes politicas brasileiras. Belo Horizonte: Itatiaia; São Paulo: EDUSP; Niterói, RJ: EdUFF, 1987. 